\title{
Serum Sickness Like Disease in Children
}

\author{
Çocuklarda Serum Hastalığı Benzeri Reaksiyonlar
}

\author{
๑Vildan Güngörer ${ }^{1}$, Alaaddin Yorulmaz², Ayşe Yüksel ${ }^{2}$, @Şükrü Arslan \\ 'Selcuk University School of Medicine Department of Pediatrics, Division of Pediatric Rheumatology, Konya, Turkey \\ ${ }^{2}$ Selcuk University School of Medicine Department of Pediatrics, Konya, Turkey
}

\begin{abstract}
Serum sickness and serum sickness-like reactions are the type III hypersensitivity reactions that occur in the presence of culprit agents which can be an exogenous protein, drug, bacteria, virus. Clinical symptoms usually begin in 6-21 days after exposure to antigenic stimulation. Typical clinical findings are characterised as fever (10-20\%), erythematous rash (95\%), polyarthritis and / or polyarthralgia (10-50\%), and lymphadenopathy (1020\%). There are no specific laboratory findings and diagnostic criteria for serum sickness-like reaction. Laboratory findings usually include leukocytosis, mildly increased erythrocyte sedimentation rate, and rarely proteinuria and hematuria. Even though there are no diagnostic criteria for serum sicknesslike reaction, it can be diagnosed with the presence of fever, rash, arthritis-arthralgia, lymphadenopathy, myalgia which occurs in 1-2 weeks after exposure to an agent that can trigger the disease. Recommended or achieved a consensus for the treatment of the serum sickness-like reaction doesn't occur and the information about this subject in the literature is limited by the authors' case reports who share their experiences.
\end{abstract}

Keywords: Child, hypersensitivity, rash, serum sickness
ÖZ

Serum hastalığı ve serum hastalığı benzer reaksiyonlar belli antijenlerin varlığında ortaya çıkan tip III hipersensitivite reaksiyonudur. Semptomlar antijenik uyarıya maruziyet sonrası genelde 6-21 gün sonra başlar. Tip III hipersensitivite reaksiyonuna sebep olan antijen ekzojen yabancı bir protein, ilaç, bakteri, virüs olabilir. Tipik klinik bulgular ateş (\%10-20), eritamatöz döküntü (\%95), poliartrit ve/veya poliartralji (\%1050) ve lenfadenopati (\%10-20) ile karakterizedir. Serum hastalığı benzeri reaksiyon için spesifik labaratuvar bulguları ve tanı kriteri bulunmamaktadır. Labaratuvar bulgularında genellikle Iökositoz, hafif artmış eritrosit sedimentasyon hızı ve nadiren proteinüri ve hematüriyi içermektedir. Serum hastalığı benzeri reaksiyonun tanı kriterleri bulunmamakla birlikte hastalığı tetikleyebilecek bir ajana maruziyetten 1-2 hafta sonra gelişen, başka bir nedene bağlanamayan ateş, döküntü, artrit-artralji, lenfadenopati, myalji kliniği ile tanı konulur. Serum hastalığı benzeri reaksiyonda önerilen ve görüş birliği sağlanmış bir tedavi şekli bulunmamaktadır. Bu konuyla ilgili literatürde daha çok yazarların kendi deneyimlerini paylaştıkları vaka bildirimleri mevcuttur.

Anahtar Kelimeler: Çocuk, döküntü, hipersensitivite, serum hastalığı

\section{INTRODUCTION}

Although the exact frequency of hypersensitivity reactions is not known, it is reported around 7\% (1) and it occurs in recurrent exposures, not in the first exposure of antigen. In 1970s, Coobs and Gell described four types of hypersensitivity reactions that named as type I, II, III and IV (2).

Serum sickness and serum sickness-like reactions (SSLR) are the type III hypersensitivity reactions that occur in the presence of culprit agents. Type III hypersensitivity reactions occur through immune complexes and localized and systemic reactions may exist. For the localized reaction forms, after intradermal or subcutaneous administration of the antigen, immune complexes with circulating antibodies can be observed. Neutrophil migration happens in the region of immune complex storage and causes regional tissue damage. 
For the systemic reaction, when the antigen enters into the circulation, it creates immun complexes there with the antibody. If the antigen is a small amount, immune complexes can be eliminated by phagocytes, but if the antigen load is high, they accumulate in the tissues (3-5).

Symptoms usually begin in 6-21 days after exposure to antigenic stimulation. The antigen that causes type III hypersensitivity reaction can be an exogenous protein, drug, bacteria, virus. Typical clinical findings are characterised as fever, erythematous rash, polyarthritis and / or polyartralgia and lymphadenopathy. Muscle pains, peripheral edema, chest pain, shortness of breath and glomerulonephritis are rarely observed in patients (6).

Although patients seem to be very sick in the feverish period, the disease limits itself. The elimination of the culprit agent that causes the disease, symptomatic treatment, and for some cases nonsteroidal antiinflammatory drugs and glucocorticoids are the basis of treatment $(6,7)$.

In this article, our aim is to draw the attention of a clinician to SSLR.

\section{ETIOLOGY AND EPIDEMIOLOGY}

Classic serum disease was first described in 1905 as a selflimiting type III hypersensitivity reaction that developed in some patients following administration of diphtheria antitoxin derived from horse serum (8). This study indicated that clinical symptoms appeared after for a length of time as the administration of diphtheria antiserum and the time was shortened when the serum was re-administered. After the use of various drugs, there are similar clinical reactions with serum-sickness but with different mechanisms. These are generally referred to as serum sickness-like reactions (SSLR). SSLR can also be seen after infections (especially streptococcal infections, tuberculosis and some viral infections such as hepatitis), drugs and post vaccination $(9,10)$. Serum sickness-like reactions are more common in children than serum sickness. Risk factors include the dose (high-dose causes high-risk) and the mode of use (the risk of intermittent use is higher than continuous use) matters. Commonly accused drugs include antibiotics (cephalosporins, clarithromycin, ciprofloxacin, penicillin, minocycline), anticancer agents, anticonvulsants, antidepressants, antidisritmics, antihypertensives and nonsteroidal antiinflammatory drugs. Existing studies in the literature reveal that SSLR ensues after insulin (11). In addition, we believe that the foods which increase intestinal permeability such as monosodium glutamate, trehalose and fructose can cause SSLR.

As the efficient research has not been done until recent years, there is no clear data about the incidence in the children. Even though there are some claims on the references that refer SSLR is seen rarely in childhood, it is observed that they are more frequent than it was thought as the studies are being performed. Epidemiological study in the pediatric patients with serum sickness-like reaction was first performed in the late 1970s and it was reported as $0.06 \%-0.5 \%$ (12). Thirty percent of these were associated with the drug, and antibiotics had a ratio of sixty percent among drugs. Although SSLR occurs mostly after oral antibiotic intake, it has been defined especially after intake of cefaclor and it has been reported as 1-2\% after exposure (12). In Australia, the risk of developing this reaction after cefaclor intake was found to be $0.4 \%$ in a study in children under 6 years of age (13). In a similar study in the United States, the risk was assessed as $0.2 \%$ $(12,13)$.

\section{PATHOPHYSIOLOGY}

Type III immune complex hypersensitivity reaction is a reaction that occurs by the binding of the antibody (against a solubl antigen) with the antigen, forming an immune complex and activating the complement system as a result. The severity of the reaction is related to the size and the distribution of the immune complex. Immune complexes are frequently observed in the vessel wall, synovial membrane of joints, glomerular basement membrane in kidney and choroidal plexus in brain. The reactions begin when the immune complexes activate the complement system.

Type III hypersensitivity reaction may be local or systemic. In the localized reaction, intradermal or subcutaneous administration of the antigen forms immune complexes with the circulating antibodies. By the neutrophil migration to the region of immune complex storage, regional tissue damage develops, edema and erythema occurs. This reaction that develops within 4-8 hours, is called acute Arthus reaction. For the systemic reaction, when the antigen enters the circulation, the immune complexes are formed in the circulation with the antibody. If the antigen has a small amount, the immune complexes can be eliminated by phagocytes, but if the antigen is overloaded the immune complexes accumulate in the tissue. The most classic type of type III reaction is Serum Sickness. During the days or weeks after the injection of the exogenous serum; symptoms as fever, malaise, edema and erythema with widespread vasculitic rashes, lymphadenopathy, arthritis and glomerulonephritis may appear $(14,15)$. Similar reactions are sometimes seen after the use of drugs and are defined as SSLR. Although they mimic clinically similar conditions, SSLR is more common and these two conditions are need to be distinguished. $(3,16,17)$. Serum sickness is an immune complex mediated type III hypersensitivity reaction to exogenous, nonhuman proteins. Laboratory investigation finds associated hypocomplementemia (C3 and (4) and proteinuria. 
In contrast, serum sickness-like reaction is probably a nonimmune complex-mediated reaction to drugs and does not manifest hypocomplementemia or renal involvement (18). The pathogenesis of SSLR is not well understood. Although it is unclear which mechanism of SSLR reactions occur with, it is thought to be by/with a hapten that is binded to plasma proteins and activated the immunological response (19).

To our considerations immune complexes against various antigenic stimuli occur frequently in the circulation. Specially after increasing the consumption of drugs and packaged food, the immune complex reaction to these antigenic stimuli is gradually increasing. If the size of these immune complexes is micro, they are filtered from the glomeruli, but the larger immune complexes are seen and captured by the phagocytic system (neutrophil, macrophage) and cleared from the body so do not cause any hypersensitivity reaction. However, when the medium-sized immune complexes are made in large amounts, they accumulate in the tissues where they find the appropriate receptors (Figure I).

We believe that immune complexes activate neutrophils and macrophages by creating a direct immunologic response when they find the appropriate tissue receptor without activation of complement and tissue damage occurs due to the release of cytokines, vasoactive amines, enzymes to the environment (20).

The hypothesis about the development of a genetically abnormal inflammatory response to drug metabolites is also suggested in the pathogenesis of SSLR (21). Invivo drug biotransformation studies about this subject have shown that lymphocytes are more activated and more capable of killing in patients with a history of SSLR than the control group. Some studies suggest that antibiotics change intestinal mucosal permeability and induce the development of SSLR exist. (22-24).

\section{HISTOPATHOLOGY}

Histopathological findings of patients with SSLR were found nonspecific, patients with accumulation of perivascular lymphocyte, eosinophil, neutrophil and one patient with histiocyte accumulation were observed. Findings were consistent with urticarial perivascular infiltration but not consistent with vasculitis whereas serum sickness diseases often have neutrophil predominant inflammation or leukocytoclastic vasculitis with skin biopsy $(25,26)$. Similar histopathological findings were obtained by Bunick et al. in another study in 2011 in which they evaluated histopathological findings of a patient (27). Finally, in 2017, the Nguyen et al. and in 2019 Tan et al. was found the neutrophilic urticarial pattern in histopathological evaluation of SSLR $(28,29)$.

With the contribution of these studies it is possible to disclore that the skin findings of serum sickness-like reaction are not consistent with a typical vasculitis. However, the limited number of studies on this subject is not sufficient to reach a definite conclusion.

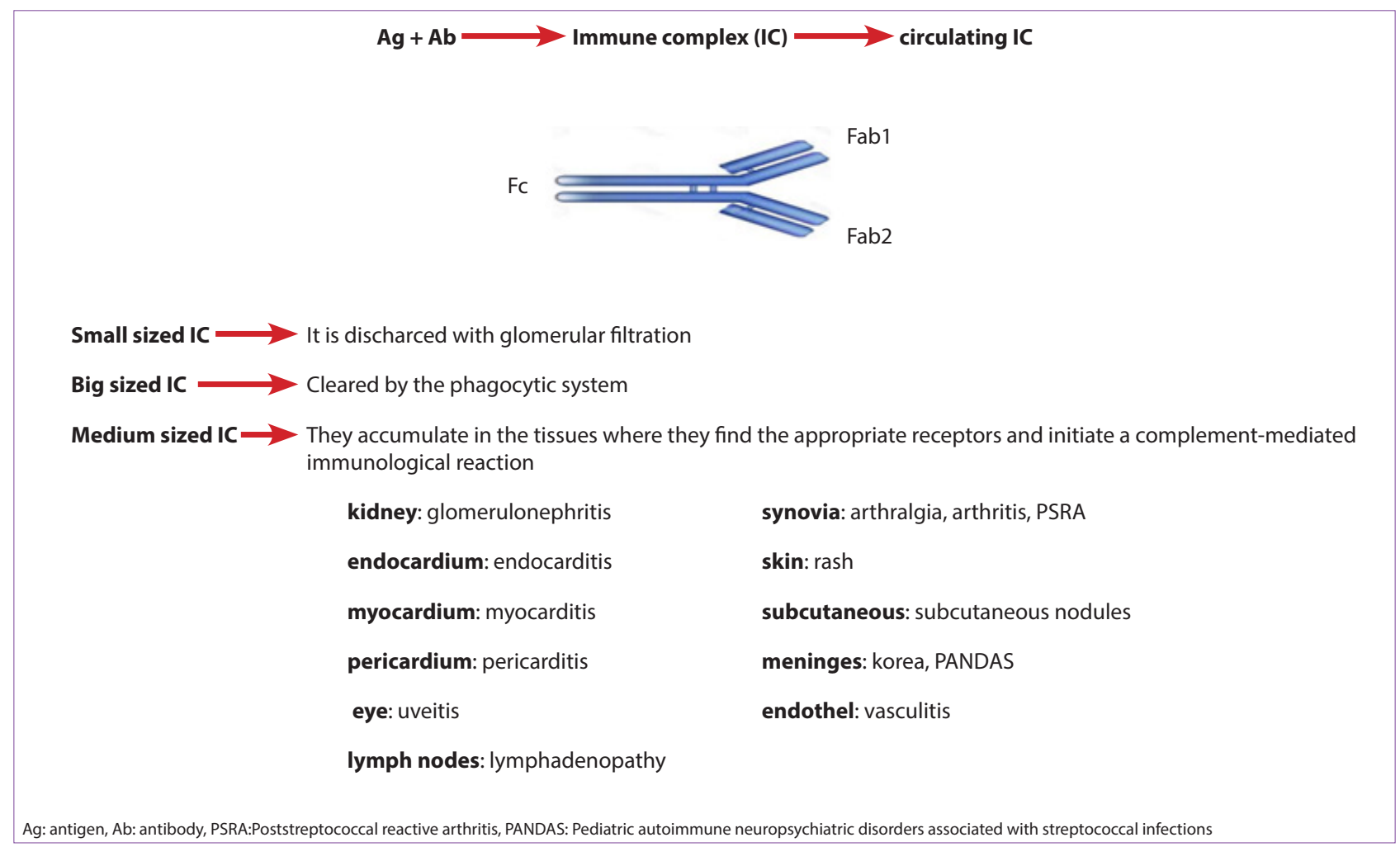

Figure 1. Pathophysiology of Tip III hypersensitivity reactions 


\section{CLINICAL SYMPTOMS AND FINDINGS}

SSLR is a clinically diagnosed disease with fever, rash, polyarthralgia and polyarthritis. Symptoms are usually seen 6-21 days after exposure and skin rash (95\%), lymphadenopathy (10-20\%), arthralgia (10-50\%) fever $(10-20 \%)$ is observed in patients. Patients may also experience muscle pain, chest pain, peripheral edema, difficulty in breathing, rarely neurological and myocardial involvement, dyspnea with or without pulmonary infiltrates, hepatosplenomegaly, gastrointestinal symptoms, renal complications and serositis can be observed in patients $(16,17)$. In our country, the widest study of SSLR series which is performed by Yorulmaz et al. detected rash in $89.7 \%$, arthritis in 51.7\%, fever in $41.40 \%$, arthralgia in $37.9 \%$, abdomen pain in $20.7 \%$, lymphadenopathy in $10.3 \%$ of the patients and pleural effusion in only one patient (3.44\%) (30). Urticaria is the most common skin rash and may be itchy. Other cutaneous symptoms such as morbiliform, papular, maculopapular, palpable purpura, scarlatiniform, erythema multiforme-like rashes can be seen. In some studies palmar erythema, livedo reticularis and periungual hemorrhage have also been described $(31,32)$. Ulcer secondary infection, vesicular rash are not common. Mucosal rash is not expected, sometimes rashes may be too different to describe (32). Unlike urticaria, the lesions tend to remain stable and do not wither in 24-36 hours. Usually an ecchymotic characteristic rash accompanied by periocular edema is observed $(33,34)$. Since the rashes are compound with meningococcemia, patients who have been performed with diagnostic lumbar punctures were present in the literature (30). Rash is usually seen earlier than other findings $(21,35)$. Typically, rashes begin at the anterior lower part of the body, in the periumbilical or axillary region and spreads to the upper part of the body and extremities. These rashes may start and spread on the palmar or plantar faces in the joints of the hands and feet (36).

Fever, malaise, lymphadenopathy, myalgia, symmetrical arthritis of the knee and metacarpophalangeal joints and artalgia are the most common clinical features after rash $(16,17)$. Elbows, knees and ankles are the most affected joints (31). Neurological involvement, gastrointestinal symptoms and renal complications may also occur in patients $(16,17)$. The fever is usually $>38,5^{\circ} \mathrm{C}$ and it spontaneously elevates in the daytime and then spontaneously returns to normal and chills does not accompany. Though the fever increases and decreases during the day, it does not show specific changes in a part of the day. When the fever increases in patients, malasia is usually seen. Arthralgia and arthritis are more common in the knee and metacarpophalangeal joints, but can also be seen in other joints including the wrist, the ankle and shoulders (37). Joint involvement usually occurs after the rash and disappears before the rash disappears. Other rare findings include nonspesific headache, blurred vision, anterior uveitis, and peripheral neuropathy involving the guillan barre syndrome (35).

\section{LABORATORY FINDINGS}

Specific laboratory findings and diagnostic criteria for SSLR don't exist. Laboratory findings usually include leukocytosis, mildly increased erythrocyte sedimentation rate, rarely proteinuria and hematuria $(6,7)$.

Unlike serum sickness, circulating immune complexes and low complement levels are not observed. Eosinophilia is not usually seen $(16,17,38,39)$. Yorulmaz et al. reported that 10 of 29 patients had leukocytosis and 17 had elevated erythrocyte sedimentation rate on their study (30). Other patients showed normal laboratory findings. Although some studies have shown increased liver function tests, it is not clear whether this is due to SSLR or etiology of SSLR (40). Moreover, it should be noted that hypoalbuminemia develops in patients with edema and findings may be observed in systemic involvement according to the organ held although the systemic involvement is not frequent. Although the biopsy is not diagnostic, the results are consistent with the neutrophilic urticarial pattern in patients who underwent biopsy $(28,29)$.

\section{DIAGNOSIS}

Although there are not diagnostic criteria for SSLR, diagnosis is made with the clinical symptoms and findings such as fever, rash, arthritis-arthralgia, lymphadenopathy and myalgia which develops 1-2 weeks after exposure to an agent that can trigger the disease. Mucosal membranes are not involved. The most frequent cutaneous findings include macular exanthem, urticarial eruption which may have dusky to purple centers, and eruption mimicking erythema multiforme. The other primary clinical feature is joint involvement manifesting with arthralgia and swelling. The hallmark of SSLR is its benign outcome. The acute phase reactants are slightly high. The other labaratory tests, including C3 and C4 levels, are normal.

\section{DIFFERENTIAL DIAGNOSIS}

In the differential diagnosis, some viral infections, hypersensitivity vasculitis, acute meningococcal or gonococcal infection, urticaria multiforme, urticarial vasculitis, Lyme disease, acute rheumatic fever, systemic juvenile idiopathic arthritis (sJIA), Kawasaki diseases, serum sickness, systemic lupus erythematosus (SLE), reactive arthritis, septic arthritis, subacute endocarditis and other types of drug reactions should be considered. Fever lasts longer than two weeks 
in SJIA and general condition disorder is dominant. Rash occurs at the time of fever and also acute phase reactants are significantly higher. Viral serology must be studied for the differentiation of viral systemic disease. Urticarial vasculitis is a type III hypersensitivity reaction such as SSLR but rash doesn't accompany fever and lymphadenopathy also compleman C4 level decreases in blood. When annuler lesions are seen in urticaria multiforme, joint involments aren't seen, more over lesions are wandering and do not seen more than 24 hours. Erythema migrans are typical for Lyme disease. There is a suspicious history that will make us think of lyme. Erytema marginatum in acute rheumatic fever is very difficult to see and the presence of typical major symptoms of the disease, previous evidence of group A beta hemolytic streptecoccal infection leads to diagnosis. Mucosal involvement with refractory fever is common in Kawasaki disease but arthritis/arthralgia is not prominent. None of the laboratory and physical examination findings that meet the typical diagnostic criteria in seen SLE is seen SSLR. Differential diagnosis from other drug reactions is difficult. It is distinguished from drug rash with eosinophilia and systemic symptoms (DRESS) syndrome by lack of eosinophilia. Also SSLR differs from other drug reactions with the prominence of arthritis/arthralgia. SSLR is a diagnosis of exclusion if we cannot find other diseases in the presence of appropriate findings, it should come to mind because of the increasing number of patients.

Generally it occurs after the exposure to antibiotics, accompanied by fever, myalgia, arthritis / arthralgia, lymphadenopathy and lack of facial and acral edema and mucous membrane involvement. The patient's general condition despite the fever is well. There isn't any pathological laboratory examination except the leukocytosis, neutrophilia, moderate elevation of sedimentation and C-reactive protein. With these properties, it is a diagnosis of exclusion from other diseases.

\section{TREATMENT}

Treatment of choise or consensus for SSLR don't exist. Treatment generally consists of distraction of the causative agent of SSLR and symptomatic treatment. Avoiding the culprit agent is the primary treatment. Nonsteroidal antiinflammatory (NSAID) drugs, antihistamines and varying doses of steroids due to the experience of the clinic can be applied for symptomatic treatment (11). For the distraction, it is being avoided if the agent is known, also there are some studies that performs plasmapheresis in the literature (11).

Paterson-Fortin et al. (36) reported that patients benefit from the nonsteroidal antiinflammatory treatment. However, it has been reported that clinical recovery was usually observed after steroid treatment, steroid is usually administered at a dose of $1 \mathrm{mg} / \mathrm{kg}$ as the prednisolone form for about 4 weeks and the centers who administer low-dose methylprednisolone exist $(11,37,41,42)$. Brucculeri et al. reported that they destroyed the clinical signs after 5 days of treatment with prednisolone $20 \mathrm{mg}$ twice Daily (17). Tatum et al. reccommend the treatment of prednisolone for 2 weeks in the form of 40-60 mg / day (43).

In the literature on this subject, there are more case reports where the authors share their experiences. (4446).

As we could not cure with antihistaminics and nonsteroidal antiinflammatory treatment in our unit, we treat the patients who diagnosed with SSLR first 3-6 days $10 \mathrm{mg} / \mathrm{kg}$ and the following 3-6 day $5 \mathrm{mg} / \mathrm{kg}$ methylprednisolone and $1 \mathrm{mg} / \mathrm{kg}$ oral prednisolone decreasingly after 4 weeks of treatment. With this treatment, complete clinical improvement was achieved in all of our patients and no relapse was observed in any of our patients. Although we have not done any comparative study on this subject, we recommend the use of this treatment scheme developed in accordance with our clinical experience in patients with SSLR.

\section{CONCLUSION}

After increased usage of the various antigenic stimuli, specifically antibiotic use, the development of serum sickness-like reaction is defined increasingly. As studies on this subject increase, clinicians will recognize better this reaction and develop a common treatment modality in the future. Our purpose is to define this situation in the light of current data and to create awareness among physicians about this subject.

\section{ETHICAL DECLARATIONS}

Referee Evaluation Process: Externally peer-reviewed.

Conflict of Interest Statement: The authors have no conflicts of interest to declare.

Financial Disclosure: The authors declared that this study has received no financial support.

Author Contributions: AConseptualization and Methodology; V.G, A.Y, A.Y, Software; A.Y, V.G, Validation; Ş.A, V.G, Formal Analysis; Ş.A, A.Y, V.G, Investigation; V.G, Ş.A, Resources; V.G, A.Y, A.Y, Data Curation; V.G, Ş.A, Writing-Original Draft; V.G, Ş.A, Preparation; V.G, A.Y, Writing-Review Editing; V.G, Ş.A, A.Y, Visualization; V.G, A.Y,A.Y, Supervision; V.G, Ş.A, Project Administration; V.G, Ş.A

This article does not contain any studies with human patticipants or animals performed by any of the authors. 


\section{REFERENCES}

1. Lundquist $A L$, Chari RS, Wood JH, et al. Serum sickness following rabbit antithymocyte globulin induction in a liver transplan recipient: case report and literature review. Liver Transpl. 2007;13: 647-50.

2. Gell PGH, Coombs RRA. Classification of allergic reactions responsible for clinical hypersensitivity and disease. In: Gell PGH, Coombs RRA, Hachmann PJ (eds). Clinical Aspects of Im munology. Oxford, England: Blackwell Scientific Publications, 1975: 761-81.

3. Solensky $R$, Khan DA. Drug allergy: an updated practice parameter. Ann Allergy Asthma Immunol. 2010;105:1-77.

4. Chen SM. Serum sickness. Emedicine Web site. http://www. emedicine. com/emerg/ Accessed February 19, 2008.

5. Johnson BA, Nunley JR. Use of systemic agents in the treatment of acne vulgaris. Am Fam Physician. 2000;62(8):1823-1830, 18351836.

6. Von Pirquet CF, Schick B. Die Serum Krankheit. Franz Deutiche Leipzig Wien 1905. (English translation by Schick B:Serum Sickness. Baltimore: Williams \& Wilkins, 1951)

7. Apisarnthanarak A, Uyeki TM, Miller ER, et al. Serum sicknesslike reaction associated with inactivated influenza vaccination among Thai health care personnel: risk factors and outcomes. Clin Infect Dis. 2009; 49: 18.

8. Arkachaisri T. Serum sickness and hepatitis B vaccine including review of the literature. J Med Assoc Thai. 2002; 85 2: 607.

9. Misirlioglu ED, Duman $H$, Ozmen $\mathrm{S}$, et al. Serum sickness-like reaction in children due to cefditoren. Pediatr Dermatol. 2012;29: 327-8.

10. Sohail MA, Nasir J, Ikram U, et al. Serum Sickness-Like Reaction with Clarithromycin. Journal of Hospital Medicine. 2011;6: 231232.

11. Parshuram CS, Phillips RJ. Retrospective review of antibioticassociated serum sickness in children presenting to a paediatric emergency department. Med. J. Aust. 1998; 169: 116.

12. Levine LR. Quantitative comparison of adverse reactions to cefaclor vs amoxicillin in a surveillance study. Pediatr. Infect. Dis. J.1985; 4: 358-61.

13. Dyall D, Smith FACD. Serum sickness-like reaction. Dermatologist; 2009.

14. Doan T, Melvold R, Viselli S, et al. İmmünoloji Lippincott. Nobe Matbaacılık, 2013, İstanbul.

15. Barnes P. Pathophysiology of Allergic Inflammation. In: Franklin N, Adkinson JR. William WB . editors. Middleton's Allergy E-Book: Principles and Practice. 8th edition, Vol 1, Section A, Chapter 21.

16. Katta R, Anusuri V. Serum sickness-like reaction to cefuroxime: a case report and review of the literature. J Drugs Dermatol. 2007; 6: 747-748.

17. Brucculeri $M$, Charlton $M$, Serur D. Serum sickness-like reaction associated with cefazolin. BMC Clin Pharmacol. 2006; 6: 1-3.

18. Bolognia JL, Schaffer JV, Cerroni L. 4th ed. Elsevier; Edinburgh: 2017. Dermatology: 2-Volume Set.

19. Knowles $\mathrm{SR}$, Uetrecht J Shear $\mathrm{NH}$. Idiosyncratic drug reactions: the reactive metabolite syndromes. Lancet 2000; 356:1587-1591.

20. D. Male, J. Brostoff, D. Roth, et al. Immunology 7th Ed. Elsevier, 2006.

21. Lawley TJ, Bielory L, Gascon P, et al. A prospective clinical and immunologic analysis of patients with serum sickness. $\mathrm{N}$ Engl J Med. 1984; 311:1407-1413.

22. Zhang Z, Xiang Y, Wang B, et al. Intestinal mucosal permeability of children with cefaclor-associated serum sickness-like reactions Eur J Pediatr. 2013; 172: 537-43.

23. Lanas Á, Scarpignato C. Microbial flora in NSAID induced intestinal damage: a role for antibiotics? Digestion. 2006; 73: 136-150.

24. Linskens RK, Huijsdens XW, Savelkoul PH, et al. The bacterial flora in inflammatory bowel disease: current insights in pathogenesis and the influence of antibiotics and probiotics. Scand J Gastroenterol Suppl. 2001; 234: .29-40.

25. Yerushalmi J, Zvulunov A, Halevy S. Serum sickness-like reactions. Cutis. 2002;69: 395-7.

26. Swanson J, English JC 3rd. Serum sickness-like reaction to Pamabrom. J Drugs Dermatol. 2006; 5: 284-6.

27. Tolpinrud WL, Bunick CG, King BA. Serum sicknesselike reaction: histopathology and case report. J Am Acad Dermatol. 2011; 65 83-85.
28. Nguyen CV, Miller DD. Serum sickness-like drug reaction: two cases with a neutrophilic urticarial pattern. J Cutan Pathol. 2017; 44: 177-82.

29. Tan MG, Burns BF, Glassman SJ. Serum sickness-like reaction associated with mirabegron. JAAD Case Rep. 2019 Jun 8;5(6):537539. doi: 10.1016/j.jdcr.2019.04.010.)

30. Yorulmaz A, Akın F, Sert A, et al. Demographic and clinical characteristics of patients with serum sickness-like reaction. Clin Rheumatol. 2018; 37: 1389-94.

31. Diaz L, Ciurea AM. Cutaneous and systemic adverse reactions to antibiotics. Dermatol Ther. 2012; 25: 12-22.

32. King BA, Geelhoed GC. Adverse skin and joint reactions associated with oral antibiotics in children: the role of cefaclor in serum sickness-like reactions. J Paediatr Child Health. 2003; 39: 677-81.

33. Noguera-Morel L, Hernández-Martín Á, Torrelo A. Cutaneous drug reactions in the pediatric population. Pediatr Clin North Am. 2014; 61: 403-26.

34. Song JE, Sidbury R. An update on pediatric cutaneous drug eruptions. Clin Dermatol. 2014; 32: 516-23.

35. McCollom RA, Elbe DH, Ritchie AH. Bupropion-induced serum sickness-like reaction. Ann Pharmacother. 2000; 34: 471-3.

36. Patterson-Fortin J, Harris $\mathrm{CH}$, Niranjan-Azadi A, et al. Serum sickness-like reaction after the treatment of cellulitis with amoxicillin/clavulanate. BMJ Case Rep 2016. doi:10.1136/bcr2016-217608

37. Baniasadi S, Fahimi F, Mansouri D.Serum sickness-like reaction associated with cefuroxime and ceftriaxone. Ann Pharmacother 2007:41: 1318-1319.

38. Nayak S, Acharjya B. Adverse cutaneous drug reaction. Indian J Dermatol 2008;53: 2-8.

39. Ralph ED, John M, Rieder MJ, et al. Serum Sickness-like Reaction Possibly Associated with Meropenem Use. Clinical Infectious Diseases 2003; 36: 149-51.

40. Vial T, Pont J, Pham E, et al. Cefaclor-associated serum sicknesslike disease: eight cases and review of the literature. Ann Pharmacother. 1992; 26: 910.

41. Chiong FJK, Loewenthal M, Boyle M,et al. Serum sickness-like reaction after influenza vaccination. BMJ Case Rep 2015. doi:10. 1136/bcr-2015-211917.

42. Mathes EF, Gilliam AE. A four-year-old boy with fever, rash, and arthritis. Semin Cutan Med Surg. 2007; 26: 179-87.

43. Tatum AJ, Ditto AM, Patterson R. Severe serum sickness-like reaction to oral penicillin drugs: three case reports. Ann Allergy Asthma Immunol 2001; 86: 330-4.

44. Finger $E$, Scheinberg M. Development of serum sickness-like symptoms after rituximab infusion in two patients with severe hypergammaglobulinemia. J Clin Rheumatol. 2007; 13: 94.

45. LoVecchio F, Welch S, Klemens J, et al. Incidence of immediate and delayed hypersensitivity to Centruroides antivenom. Ann Emerg Med. 1999; 34: 615.

46. Joubert Gl, Hadad K, Matsui D, et al. Selection of treatment of cefaclor-associated urticarial, serum sickness-like reactions and erythema multiforme by emergency pediatricians: lack of a uniform standard of care. Can J Clin Pharmacol. 1999; 6: 197. 